In deze rubriek worden zowel methodologieboeken besproken als onderzoeksrapportages, bij voorkeurvan Nederlandstalige auteurs. Auteurs krijgen de gelegenheid om op de recensie te reageren. Op de website www.kwalon.nl worden regelmatig boeken ter recensie aangeboden. Wie een boek wil bespreken (al dan niet uit dat aanbod), kan zich richten tot redacteur Famke van Lieshout: f.vanlieshout@fontys.nl.

\title{
Het lezen van afbeeldingstechnieken
}

\author{
Fred Wester
}

Gunther Kress \& Theo van Leeuwen, Reading images. The grammar of visual design (2nd ed.). London: Routledge, 2006, 291 pagina's, ISBN 978-0-415-31915-7, € 29,99.

Het boek Reading images richt zich op de structuren die in afbeeldingen zijn te herkennen en probeert dus hulpmiddelen aan te dragen die voor het lezen van afbeeldingen van belang kunnen zijn. De term Grammar verwijst naar de taalkunde, naar de regels achter het taalgebruik. In die zin moet the grammar of visual design niet worden opgevat. Het gaat niet om vaste of juiste regels voor de afbeeldingsbouw en hoe zij de interpretatie sturen of de boodschap bepalen. Het boek is meer een ontdekkingstocht naar de (verschillende) gewoonten die er zijn, vroeger en nu, als het gaat om afbeeldingen als tekeningen, schilderijen, foto's, schema's, diagrammen, en ook sculpturen. Het gaat dus meer om hoe de basiselementen (objecten, mensen, ruimte, tekens) gebruikt worden om een betekenisvolle afbeelding te maken. Het doel is te reconstrueren welke compositionele structuren doorgaans gebruikt worden en te analyseren hoe daarmee betekenis wordt geproduceerd. Zoals linguïstische structuurelementen (bijvoorbeeld actieve werkwoorden) de betekenis sturen, zo is de gedachte, zo wijzen ook visuele structuurelementen op bepaalde betekenisingangen. Het gaat erom die structuurelementen te leren kennen, niet om de interpretatie van de boodschap van de afbeelding te onderbouwen.

Het boek bestaat uit negen thematische hoofdstukken, voorafgegaan door een theoretische introductie. In de visuele communicatie spelen drie hoofdfuncties een rol: de uitdrukking van relaties tussen objecten (hoofdstuk 2 en 3), de uitdrukking van de relatie tussen maker en ontvanger van de afbeelding (hoofdstuk 4 en 5), en het gebruik van tekstuele karakteristieken zoals compositie, materialen en kleur (hoofdstukken 6 t/m 9).

In de introductie gaan de auteurs in op hun semiotische representatietheorie en leggen zij uit wat zij onder visual grammar verstaan. Hoewel het idee van visual grammar is ontleend aan de taal met haar structuren, is er een groot verschil: de grammars van bijvoorbeeld het Engels, Nederlands en Frans zijn nogal verschillend, maar in de beeldtaal is er meer sprake van een dominante westerse cultuur (gewoonten, manieren) van afbeelden met name in bepaalde domeinen van het openbare leven (zoals bijvoorbeeld het verkeer: vliegvelden, havens, snelwegen). De structuurelementen van die dominante beeldtaal staan hier centraal. De auteurs benaderen de structuurelementen vanuit het centrale 
semiotische idee van het teken: een vorm met een betekenis verwijzend naar een betekenissysteem. Het teken is gemotiveerd: de maker gebruikt een vorm om een betekenis uit te drukken. Vormelementen worden hier dan ook als bewuste keuzen opgevat, waarvan de betekenis duidelijk kan worden als je een variatie daarop in gedachten zou nemen. In het eerste hoofdstuk (The semiotic landscape: language and visual communication) worden taal en beeld als variaties in uitdrukkingssystemen besproken. De auteurs wijzen op het grote belang van het visuele in de moderne samenleving, en de geringe aandacht daarvoor in het onderwijs. Zo mogen kinderen in de laagste klassen nog heel veel tekenen, maar in de rest van het onderwijs staat volgens hen verbal literacy centraal. Beide moeten worden opgevat als uitdrukkingsvormen van de cultuur in een samenleving, maar de verbale vorm wordt als veel belangrijker gezien.

De auteurs zetten zich af tegen het idee van de semioloog Roland Barthes, dat de betekenis van een afbeelding afhankelijk is van verbale explicatie. Zij benadrukken terecht dat de visuele tekst onafhankelijk is, dat deze een eigen symboolsysteem is naast het verbale. Maar in hun promotie van het visuele verwarren zij betekenisoverdracht met de sociale processen van betekenisuitleg en controle op gedeelde inzichten. De rest van het boek maakt duidelijk dat de explicatie van die betekenissen naar de lezers toe voornamelijk verbaal gebeurt, waarbij plaatjes of tekeningen hulpmiddelen zijn. Weliswaar is de betekenis van het visuele niet afhankelijk van het verbale, en de overdracht ook niet, maar de onderbouwing daarvan en de controle op gedeelde betekenis, zijn dat in onze cultuur wel.

In hoofdstuk 2 (Narrative representations: designing social action) worden de visuele structuren besproken die worden gebruikt om sociale handelingen en de (ideologische) lading die zij hebben, te representeren. Een handeling of proces geeft een richting aan en de belangrijkste visuele techniek is uitdrukking geven aan die richting. In procesdiagrammen bijvoorbeeld gebeurt dit door het gebruik van pijltjes. Als het om actiefoto's of actie-tekeningen gaat, is er een relatie tussen Actor en Doel. Die relatie wordt meestal afgeleid van de richting waarin de Actor kijkt. Die richting keert in tekeningen terug in het gebruikte perspectief van de tekening. Ook voor foto's kan het perspectief van waaruit de foto is gemaakt hier mede een richting benadrukken. Dit kan ook gebruikt worden voor manipulatie en suggestie: door een object in de blikrichting te plaatsen wordt een afgebeelde persoon een actor met een intentie!

In hoofdstuk 3 (Conceptual representations) gaat het om het uitdrukken van betekenissen van sociale constructen. Een mooi voorbeeld zijn classificatiesystemen zoals die uitgedrukt worden in de vorm van een boomstructuur: elementen staan in relatie tot elkaar geordend en dat geeft zo ook de betekenissen van het overkoepelende begrip aan. Andere afbeeldingen zijn meer analytisch van aard. Een abstract schilderij is bijvoorbeeld te zien als een boodschap over de relaties tussen kleuren of vormen.

In hoofdstuk 4 (Representation and interaction) gaat het om de relatie van het afgebeelde met de kijker/lezer. Is het afgebeelde een persoon en kijkt die de lezer recht aan, dan geeft dat de suggestie dat er een beroep op je wordt gedaan. De relatie tussen afgebeelde en lezer/kijker wordt ook beïnvloed door perspectief en afbeeldingframe. Een close-up suggereert (sociale) nabijheid, een overzichtfoto suggereert afstand. Frontale weergave 
suggereert betrokkenheid, een zijdelingse weergave afstand, van onderop genomen geeft macht aan de afgebeelde persoon, van bovenaf weergegeven suggereert nietigheid.

In hoofdstuk 5 (Modality) gaat het over realiteitsmodellen, dat wil zeggen suggesties over de realiteitswaarde van het afgebeelde. Kleur bijvoorbeeld geeft meer realiteitswaarde dan zwart/wit, omdat de wereld nou eenmaal kleur heeft. Je zou ook kunnen stellen dat zwart/wit een abstractere weergave van de realiteit is of een andere realiteitsdefinitie suggereert (bijvoorbeeld een droom). Maar kleur kan juist ook gebruikt worden om een onwerkelijke modaliteit weer te geven (alles in variaties van bruin als teken van een bijzondere werkelijkheid, bijvoorbeeld onder invloed zijn). Andere indicaties voor realiteitsvariatie kunnen worden gemaakt met detail, perspectief of context van het afgebeelde. Ze kunnen meer realiteitswaarde geven, maar ook te veel, zodat er een andere modaliteit wordt gesuggereerd.

In hoofdstuk 6 (The meaning of composition) gaat het over de tekens die met compositie te maken hebben. De informatiewaarde van een tekst komt in westerse culturen van links naar rechts en van boven naar beneden, in samenhang met de leesgewoonte. Voor een afbeelding betekent dit dat we links en boven de uitgangssituatie hebben en rechts naar beneden waar we naartoe gaan, het nieuwe. In Rembrandts schilderijen betekent dat: links (licht) het gegevene, en rechts (donker) het nieuwe. Een ander compositiekenmerk, dat meer in oosterse afbeeldingen een rol speelt, is centraal versus marginaal. Centraal staat dan het gegevene, marginaal het nieuwe (waar je naartoe kan gaan), dan wel ideaal versus reëel.

In hoofdstuk 7 (Materiality and meaning) staat de materialiteit centraal, en dan moeten we meer denken aan een schilderij dan aan een foto. Er zijn in dit hoofdstuk weinig plaatjes, omdat de materialiteit van bijvoorbeeld een schilderij moeilijk valt weer te geven. Productietechnologie speelt hier een rol, van handmade naar elektronische recording technieken en digitale technieken. De penseelstreek is net als het handschrift een materieel teken dat verwijst naar de schilder of auteur (dan wel een vervalser).

In hoofdstuk 8 (The third dimension) komt ruimtelijkheid en verandering aan bod: sculpturen, film en beweging. De auteurs bieden dit aan als een eerste exploratie van de relevante aspecten van de driedimensionele visuele communicatie, uitgaande van de aspecten die in hoofdstuk 2 en 3 zijn besproken. Met veel plaatjes wordt aangetoond dat sculpturen van steen of ijzer ook een narratief aspect bevatten in de zin dat het geheel diepte en dus ook richting bevat. Ook voorbeelden van analytische representaties zijn in sculpturen terug te vinden. En verschillen tussen jongens- en meisjesspeelgoed; de grote ogen van de poppen doen een beroep (zie hoofdstuk 4: aanspreken) op de meisjes, terwijl het jongensspeelgoed (helmen, maskers bedekken de ogen) gemanipuleerd wil worden. Beeldende kunst kan ook besproken worden vanuit abstractie en detail. Voor filmtechnieken geldt dat afzonderlijke shots in volgorde gezet een samenhang kunnen suggereren, die in feite niet is gefilmd.

Hoofdstuk 9 (Colourful thoughts) bevat een analyse van het gelijknamige schilderij, waarbij de visuele technieken uit de eerste hoofdstukken worden toegepast. 


\section{Oordeel}

De ondertitel van het boek The grammar of visual design is, zo mag men concluderen, nogal overdreven. Het gaat immers niet om de grammatica die bij de afbeelding moet worden gevolgd om betekenis over te dragen. Er zijn in feite slechts aanknopingspunten geboden die gebruikt kunnen worden bij de interpretatie van het visuele, kenmerken die niet per se op een bepaalde betekenisinhoud wijzen. Die aanknopingspunten zijn niet eenduidig en sluitend wat de betekenisverlening betreft, want de visuele elementen zijn op meerdere manieren toe te passen. De betekenis, of wat de maker heeft bedoeld, is niet eenvoudig te decoderen door de hier besproken visuele elementen na te lopen. Het gaat hier dus om een formele benadering van de opbouw van de afbeelding, eigenlijk los van de vraag of de boodschap die zij moet overbrengen nu geheel duidelijk is of niet. Maar om te analyseren hoe betekenis wordt geproduceerd, moet de boodschap wel worden geïnterpreteerd, dat wil zeggen met (enkele, sommige) betekenissen worden benoemd. Mijn probleem bij het lezen van het boek was, dat ik meer lette op de betekenissen en interpretaties die de auteurs naar voren brachten (hoe komen zij erbij), dan op de relevantie van en de variaties in het gebruik van het betreffende structuurelement. Maar de auteurs hebben er ook weinig aan gedaan om dat probleem te vermijden, hoewel dat makkelijk had gekund door dezelfde afbeelding in verschillende variaties weer te geven. Dat betekent niet dat dit boek geen duidelijke bijdrage kan hebben voor de visuele mediawijsheid. De betekenis in de zin van wat de maker heeft bedoeld, is aan de hand van de visuele kenmerken meestal goed uit het werk af te leiden, als je voorgegeven krijgt wat die boodschap is. Het maakt gebruikers gevoelig voor de visuele technieken die kunnen worden toegepast. Ook zou het hier aangeboden kader gebruikt kunnen worden om na te gaan of de afbeelding kenmerken bevat die interpretatiemogelijkheden suggereren die niet bedoeld kunnen zijn. 